\title{
THE COURTS FROM THE REVOLUTION TO THE REVISION OF THE CIVIL CODE.
}

The Revolution at first caused the utmost confusion in the administration of justice in Pennsylvania. At the beginning of the conflict the influential and conservative element in the province while opposed to the measures of parliament were exceedingly adverse to the idea of a separation from Great Britain. The grievances of the Pennsylvanians were not as great as those of the New England colonists; they had a liberal charter and a satisfactory system of local government, while the proprietary family stood between them and the crown to soften controversies and prevent conflicts of authority; they earnestly hoped for reconciliation and were carried on the tide of revolution sorely against their wills. To accelerate the movement and to get rid of the conservatives, a bold minority, with the moral support of Congress, organized and carried through a revolution in the government of Pennsylvania. A convention called in July, I776, and presided over by Franklin, drew up a new constitution, which, after considerable opposition, was declared to have been adopted, Penn's charter was discarded, the proprietary government ceased to exist, the old officials and assembly retired and new men took their places.

The Constitution of 1776 was not a satisfactory instrument and was discarded after a fourteen years' trial, but some of its features are worthy of notice. The executive power was vested in a supreme executive council composed of twelve members, one from the city of Philadelphia and eleven from the respective counties. The term of office was three years, and the president and vice-president were chosen from the council by joint ballot of the assembly and council. The president and council were empowered to choose and commission all judges and other officers and fill 
vacancies. Every officer of the State was subject to impeachment by the Assembly, the impeachments to be heard before the president and council. The principal judiciary clauses were as follows:

"Section 23. The judges of the supreme court of judicature shall have fixed salaries, be commissioned for seven years only, though capable of reappointment at the end of that term, but removable for misbehaviour at any time by the general assembly; they shall not be allowed to sit as members in the continental congress, executive council or general assembly, nor to hold any other office, civil or military, nor take or receive fees or perquisites of any kind.

Sec. 25. Trials shall be by jury as heretofore, and it is recommended to the legislature of this state to provide by law against every corruption or partiality in the choice, return or appointment of juries.

Sec. 26. Courts of sessions, common pleas and orphans' courts shall be held quarterly in each city and county, and the legislature shall have power to establish all such other courts as they may judge for the good of the inhabitants of the state; all courts shall be open, and justice shall be impartially administered without corruption or unnecessary delay: All their officers shall be paid an adequate but moderate compensation for their services, and if any officer shall take greater or other fees than the laws allow him, either directly or indirectly, it shall ever after disqualify him from holding any office in this state.

Sec. 27. All prosecutions shall commence in the name and by the authority of the freemen of the commonwealth of Pennsylvania, and all indictments shall conclude with these words-against the peace and dignity of the same. The stile of all process hereafter in this state shall be The commonwealth of Pennsylvania."

The office of justice of the peace was made elective, the voters of the respective districts to choose two, one of whom was to be commissioned by the president for the term of seven years.

A peculiar feature of the constitution wastheprovision for the election every seven years of a council of censors who were to meet and inquire whether the constitution had been preserved inviolate, whether the laws were duly executed, and, if there appeared any necessity to amend the constitution, to call a convention for that purpose. While these changes were in progress and while most of the active citizens were engaged in war or political strife, the administration of justice was sadly neglected. The supreme court was closed during 1776 , not to resume its sittings until the new court took office in August, I777. 
By an act of January $28,1777,,^{1}$ passed for the purpose of putting into effect such and so much of the laws of the province as were necessary in the commonwealth, it was provided, that the courts of quarter sessions and gaol delivery, petty sessions, common pleas, orphans' courts, supreme court, courts of oyer and terminer and general gaol delivery should be held and kept in each respective county at the times and places appointed by law with all the powers, authority and jurisdiction which by law such justices and judges theretofore had had and exercised and such as were given by the constitution. It was further provided that the president and council should appoint one justice in each county to preside in the respective courts and in his absence the justices who should attend were to choose a president. All actions in the provincial courts were continued in the same state as if the authority of such courts had never ceased.

The chief justice of the new supreme court was Thomas McKean, a signer of the Declaration of Independence and one of the most active of the patriot party. The associate justices were William A. Atlee and John Evans. The suspension of the courts caused considerable inconvenience and letters and petitions complaining of the prevailing conditions were presented to the council. ${ }^{2}$ In the counties the same trouble was had with regard to the justices, many of whom were away, or unwilling to act in the unsettled state of affairs; in some parts of the state the local committees of safety assumed judicial power and took cognizance of minor crimes, for example a case involving horse stealing was tried by the committee for Northumberland County in 1777 .

The first session of the common pleas, at Philadelphia, when the style and process was altered from king to commonwealth, was held in September, 1777, when six at-

\footnotetext{
${ }^{1}$ IX Stat. at Large, 29.

2VI Pa. Arch. (Ist Series) 228, 245, 294; VII Pa. Arch. (Ist Series), 72; IX Col. Rec., 214, 260.
} 
torneys were admitted to practice, ${ }^{3}$ but the British were already marching on Philadelphia, and before the end of the month the entry into the city of the army of King George drove from it every vestige of the new government.

During the occupation of Philadelphia by General Howe, from September, $I 777$, to June, 1778 , the seat of government was in Lancaster. With the return of the state officials to Philadelphia the various agencies of proscription became most active. ${ }^{4}$ By Act of Assembly numerous persons were declared traitors and their estates forfeited to the commonwealth. The most important cases tried before the newly organized supreme court were treason trials, among which those of Roberts and Carlisle, which are very briefly reported, aroused the greatest popular interest ${ }^{5}$ Roberts, a prominent miller of Lower Merion Township, was accused of acting as a guide to Sir William Howe and of persuading various persons to enlist in the British army. Carlisle was specially charged with having accepted a commission to keep watch over the gates of the city of Philadelphia, established by Howe to prevent the ingress and egress of patriots. The accused were tried on the twenty-fifth and thirtieth of September, 1778 , found guilty and sentenced to be hanged. An earnest appeal for executive clemency was made to the council on behalf of the prisoners by numerous petitions, but the council was firm and both were hanged. In these, as in most of the other treason trials, James Wilson appeared for the defendants and acquired such unpopularity through his faithful efforts in behalf of his clients that his house was attacked by a mob, which was driven off only after a fight that cost several persons their lives.

The Revolution brought to an end the court of vice admiralty, of which Edward Shippen was judge, and it became necessary to create a tribunal to take its place. The Continental Congress advised the several legislatures to

${ }^{2}$ Biography of William Lewis, Pa. Mag., vol. $x x, 30$.

'X Col. Rec., 6ro, 745.

${ }^{5}$ Resp. v. Carlisle, I Dall., 35; Resp. v. Roberts, I Dall., 39, and see IX Col. Rec., 600,6 i3. 
create courts of admiralty and, accordingly, the Assembly, on March 26, I776, passed a resolution creating a court of admiralty to be held in the city of Philadelphia to try cases of captured vessels brought into that port, with the right of appeal to Congress or to such person or persons as they should appoint to hear appeals. ${ }^{6}$ For this purpose a committee was appointed by Congress, whose feeble and unsupported authority was openly defied by George Ross, the Pennsylvania judge of admiralty, in the case of the "Active," giving rise to a memorable controversy carried on in the courts long after the adoption of the Constitution of the United States, and nearly resulting in an armed conflict between the Federal and State authorities. This case or rather series of cases pointedly illustrates the growth of the Federal power, the decree of the helpless commissioners of admiralty of the Continental Congress, long flouted by the State judges, prevailing after many years by virtue of a judgment of the Supreme Court of the United States, to whose authority the State officials, after calling out the militia to resist the marshal, yielded a sullen obedience ${ }^{7}$

Francis Hopkinson, the distinguished writer, who succeeded Ross in I779, was the first State judge to undergo the unpleasant experience of an impeachment by the Assembly. This proceeding, which took place in December, I780, was the result of a complaint by the judge against Mathew Clarkson, the marshal of the court, which resulted in his dismissal. Clarkson in revenge made charges against the judge before the Assembly, which voted for his impeachment. ${ }^{8}$ The court consisted of President Reed and the council, Messrs. Smith and Galbraith, managing for the House with Attorney-General Bradford, while Judge Hopkinson was represented by James Wilson. The charges against the judge were that he had wrongfully issued a writ for the sale of the cargo of a ship, and that he had

'Journal of Congress, vol. i, 260; VIII Stat. at Large, 519.

'Ross v. Rittenhouse, 2 Dall., I60; Olmstead's Case, Brightly's Nisi Prius Rep., 9.

'Penna. State Trials (Hogan, 1794). 
exacted illegal fees in a prize case. The judgment of the council, as pronounced by the president, was an acquittal upon all the charges, although it seemed to the council that the fees, which were charged according to the recognized practice of the court, were excessive. Upon the adoption of the Constitution of the United States admiralty jurisdiction passed to the district courts and Judge Hopkinson was appointed the first district judge for Pennsylvania under the Act of Congress of September I4, I789.

The necessity for a court of last resort to take the place of the Privy Council of Great Britain was met by the creation of the High Court of Errors and Appeals, under the act of February 28, 1780, ${ }^{9}$ to hear appeals from the supreme court, the register's courts and the court of admiralty.

This act, after reciting that the laws of the late province gave a very precarious, difficult and expensive remedy to parties injured by erroneous judgments, by appeal to the king in council, and that as "the good people of this commonwealth, by their happy deliverance from their late dependent condition, and by becoming free and sovereign are released from this badge of slavery and have acquired the transcendent benefit of having justice administered to them at home and at moderate costs and charges," enacted that a court of error should be established composed of the president of the supreme executive council, the judges of the supreme court, the judge of the admiralty, together with three persons of known integrity and ability commissioned for seven years, any four or more of them to constitute a quorum. The court under this form had but a brief existence, its composition being materially changed by the Act of April I3, I79I. ${ }^{10}$ Of the presidents of the council, Reed and Dickinson were leading lawyers and Dickinson rendered at least one very able decision in the admiralty case of Talbot v. Three Brigs. ${ }^{11}$ Benjamin Franklin, although he had once

\footnotetext{
'X Stat. at Large, 52.

"3 Smith's Laws, 28.

"I Dall., 95.
} 
sat in the common pleas, was wise enough to know that the law required a special education. At least there is no reported opinion by him while president. Of the extra members of the court Edward Shippen, judge of vice admiralty under the crown, subsequently became a justice and chief justice of the supreme court; Francis Hopkinson has been mentioned and Henry Wynkoop was president judge of Bucks County.

That the constitution of 1776 was not working smoothly was the opinion of a majority of the council of censors which met in 1783 to consider whether the constitution was being observed and whether it needed amendment. The committee on defects reported that the commissioning of the judges of the supreme court for seven years only was a material defect, because it rendered the tenure of judges dependent on the will of the council, while the committee on abuses reported that the section requiring fixed salaries for the judiciary had not been complied with as it ought and that permanent salaries should without delay be established for the judges during their continuance in office. ${ }^{12}$ The findings of the censors on these and other points were to bear fruit in the constitution of 1790 .

In 1786 a new departure was made in the jurisdiction of the supreme court, which hitherto had exercised no original jurisdiction in civil cases except in fines and common recoveries. By an act of that year issues of fact were al. lowed to be tried in banc or at nisi prius by that court in the county of Philadelphia.

A case that excited considerable interest at the time was the outlawry of Aaron Doan, one of the famous brothers who terrorized Bucks County and the surrounding country. The defendant, having been attainted of robbery, was brought into the supreme court on September 24, I784, and after hearing before the court upon several exceptions to the outlawry, all of which were overruled, execution was awarded. When the transcript of the record was remitted to the supreme executive council, in order that a warrant

\footnotetext{
${ }^{19}$ Constitutional Conventions of Pa., 70, 107.
} 
for the execution should issue, the humanity of President Dickinson seems to have been shocked that a man should be deprived of his life without a trial by jury and, accordingly, a letter was addressed to the supreme court inquiring whether there were any modern instances in England of persons being executed upon outlawry or whether that had ever occurred in Pennsylvania, and was compatible with the constitution. Technical objections to the record were also raised. ${ }^{13}$ The court replied that while not bound to give reasons for their judgment and desiring that this should not be construed as a precedent, they gave it as their opinion that under the laws of the commonwealth and the common law they had no doubt that the prisoner had been properly outlawed and had forfeited his life, but could mention no case in Pennsylvania of a person executed upon outlawry by judicial proceedings alone, but that of one Daniel Dawson who had been executed since the Declaration of Independence, in consequence of an attainder, by virtue of a proclamation of the supreme executive council and judicial proceedings thereon, in which the court awarded execution by sentence of death, no judgment having been given before. - Dickinson was still dissatisfied and addressed a special message to the Assembly on the subject, but no action was taken at that time and the humane scruples of Dickinson did not influence his successors Franklin and Muhlenberg upon the outlawry of the other Doans, Abraham and Levi. ${ }^{14}$ In fact except for the objections to the proceedings, as out of harmony with modern ideas, little sympathy would have been wasted on these desperadoes who, from all accounts, richly deserved their sentences. By an Act of September 23, I79r, ${ }^{15}$ the process of outlawry was better regulated, and by the Act of April 22, $1794,{ }^{16}$ the punishment of death was abolished for all crimes except murder in the first degree.

${ }^{12 R e s p . ~ \nabla . ~ D o a n, ~ I ~ D a l l . ~(W h a r t o n ' s ~ E d .), ~} 86$.

"XV Col. Rec, 505, 544.

${ }^{13}$ Smith's Laws, 37 .

3 Smith's Laws, 186. 
This reform was largely due to the efforts of William Bradford, who in that year became a judge of the supreme court, resigning a few years later to accept the office of attorney-general of the United States in Washington's cabinet, and whose brilliant career was cut short by an early death. Prior to this time the minutes of the supreme executive council are burdened with appeals for executive clemency and numerous orders appear for the remission of corporal punishment, as well as of death sentences. That the council had an eye to dramatic effect or were convinced of the value of mental impressions is indicated by one order in which a reprieve is granted to a prisoner "which the sheriff is not to make known to him until he be taken under the gallows."17 Executions were still public and were attended by vast crowds, drawn by the same morbid curiosity as is exhibited by their descendants who feast on the published details of the so called private executions. ${ }^{18}$

In I790 a new constitution for the State was drafted and adopted by a convention called for that purpose. The old constitution had many defects and the newly adopted constitution of the United States offered a model which many were eager to imitate. In the new constitution the legislative, executive and judicial powers were distinguished and defined according to the now classic American method, and the State was provided with a governor and a senate as well as an assembly. In remodelling the judiciary, the subject with which we are concerned, a determined but unsuccessful effort was made to establish a court of chancery. The principal changes in the judiciary were embodied in the following clauses of Article $V$ relating to the judiciary : ${ }^{19}$

"Sec. 2. The judges of the supreme court, and of the several courts of common pleas, shall hold their offices during good behaviour. But for any reasonable cause, which shall not be sufficient ground for impeachment, the governor may remove any of them, on the address of

\footnotetext{
"XV Col. Rec., 3 r.

${ }^{18}$ 12 Haz. Pa. Reg., Ir7; I3 Haz. Pa. Reg., 4.

${ }^{19}$ Constitutional Conventions of Pa., 30r, and 3 Smith's Laws, xxxix.
} 
two-thirds of each branch of the legislature. The judges of the supreme court, and the presidents of the several courts of common pleas shall, at stated times, receive, for their services, an adequate compensation, to be fixed by law, which shall not be diminished during their continuance in office; but they shall receive no fees or perquisites of office, nor hold any other office of profit under this commonwealth.

Sec. 3. The jurisdiction of the supreme court shall extend over the state; and the judges thereof shall, by virtue of their offices, be - justices of oyer and terminer and general gaol delivery in the several counties.

Sec. 4. Until it shall be otherwise directed by law, the several courts of common pleas shall be established in the following manner: The governor shall appoint in each county, not fewer than three, not more than four judges, who, during their continuance in office, shall reside in such county. The state shall be divided by law, into circuits, none of which shall include more than six, nor fewer than three counties. A president shall be appointed of the courts in each circuit, who, during his continuance in office, shall reside therein. The president and judges, any two of whom shall be a quorum, shall compose the respective courts of common pleas.

Sec. 5. The judges of the court of common pleas in each county, shall, by virtue of their offices, be justices of oyer and terminer and general gaol delivery, for the trial of capital and other offenders therein; and two of the said judges, the president being one, shall be a quorum, but they shall not hold a court of oyer and terminer or gaol delivery in any county, when the judges of the supreme court, or any of them, shall be sitting in the same county. The party accused, as well as the commonwealth, may, under such regulations, as shall be prescribed by law, remove the indictment and proceedings, or a transcript thereof, into the supreme court."

The most important changes, as will readily be seen. were the restoration of life tenure to the judges and the grouping of the counties into circuits with a president for the common pleas courts therein, a measure rendered necessary by the growth of the State, particularly in the west. By the appointment of judges learned in the law to preside over the lower courts in the respective circuits some measure of relief was afforded to the supreme court. whose work was becoming increasingly arduous.

By the Act of April I3, I79I, ${ }^{20}$ the courts were established in conformity with the new constitution. The supreme court were required to hold three terms a year and courts of nisi prius in the intervals. The State was divided into five circuits or districts (increased in 1806 to ten), each comprising a group of counties, and for each district a presi-

${ }_{3}$ Smith's Laws, 28. 
dent judge learned in the law was appointed by the governor who, with not less than three, or more than four other persons, commissioned as judges for each of the counties in the circuit, formed for such counties respectively the courts of common pleas, oyer and terminer, quarter sessions and orphans' court. The president and any two of the judges, with the register of wills, comprised the register's court.

In cases involving more than four hundred dollars, a writ of error lay from the supreme court and the register's court to the high court of errors and appeals, which was also remodelled and under this act comprised the judges of the supreme court and the presidents of the common pleas, with three other persons of known legal abilities commissioned in the same manner as the judges of the supreme court. It was further provided that such judges as should have given judgment below should be excluded from sitting on the hearing of that cause on appeal. The high court of errors and appeals sat once a year in Philadelphia. On the organization of this court Benjamin Chew, the provincial chief justice, was named as an extra member and was made president of the court, the other extra places not being filled.

By another act of the same date the salaries of the judges were fixed as follows: Chief justice of the supreme court $\mathfrak{E} 1000$, associate justices and president judge of first district $£ 600$, presidents of other districts $£_{500}{ }^{21}$ When it is remembered that these are not pounds sterling, but Pennsylvania currency, the modesty of these salaries is but too evident. Thirty shillings a day was allowed to each justice of the supreme court for travelling expenses when on circuit. In 1796 the salaries of the associate justices and the president of the first district were raised $\$ 400$ and of the other presidents $\$ 266.67$. At the time of the Constitutional Convention of 1837 , the salary of the chief justice of the supreme court was $\$ 2666$ and of the associate justices $\$ 2000$ each, with an allowance for mileage and expenses on circuit. The judges of the district courts were paid $\$ 2000$ each, as

'April 13, I79r, 3 Smith's Laws, 26. 
well as the judges of the common pleas for the first judicial district. In the other districts the president judges of the common pleas received $\$ 1600$ and the associates $\$ 140$ with mileage. ${ }^{22}$

In 1779 , further changes were made in the jurisdiction of the courts, which for some time were the subject of constant legislative experiments. As the population grew, the impracticability of keeping up the system of nisi prins sessions of the supreme court became more and more obvious, while to the suitors and the bar, the hardship and expense of crossing the Alleghenys to attend a session of the court in banc, at Philadelphia, in the days before railroads amounted to a denial of justice. But the bar was not yet prepared to give up its cherished traditions and inherited fondness for itinerant justice, and the district courts had not been long enough established to be recognized as the true solution of the problem. The Act of March 20, I799, ${ }^{23}$ therefore provided that instead of nisi prius courts, there should be held (except in the county of Philadelphia) circuit courts which were of the same nature as the court of nisi prius except that the judges holding the same were empowered to give judgment, pass decrees and award execution in as ample a manner as when sitting in banc. The right of appeal to the supreme court was preserved under special conditions.

Although not required by the act by which these courts were constituted, it continued to be the practice, as before, for two judges to ride on circuit and sit together at trials in these courts. This was unnecessary as the time of the judges could have been better distributed by sitting singly on jury trials, while trials conducted by two judges were subject to the same inconvenience as when conducted by the four judges sitting in banc, which, as Judge Brackenridge has remarked, ${ }^{24}$ caused great delay, as documents offered in evidence had to be read by all the judges in turn and a note taken by each.

"Debates of $\mathrm{Pa}$. Constitutional Convention of 1837 , vol. i, 263.

* Carey \& Bioren's Laws, 694.

'Brackenridge's Miscellany, 283. 
Trials in banc were abolished in Philadelphia by the Act of February 24, I806 (4 Smith's Laws 270), which also established a Western district for the supreme court which was required to hold its September term at Pittsburg. It was also provided that in the future circuit courts should be held by one judge and that the judges should alternate so that the same judge would not sit oftener than once in the same county in every fourth successive term. The act also abolished the high court of errors and appeals and vested its powers in the supreme court. As respects the common pleas, the state was divided into ten judicial districts and a president judge appointed in each of the new districts. It was further provided that whenever required by either party or counsel the judge should reduce his opinion to writing with his reasons and file the same of record in the cause.

By an Act of April 10, 1807,25 a middle district was established for the supreme court, the term to be held at Sunbury and again in $1809,{ }^{26}$ two additional districts were established, the Lancaster district and the southern, to be held at Chambersburg. By this act the circuit courts were abolished, and the cases undetermined therein relegated to the common pleas or, where appeals were pending, to the supreme court. The number of judges of the supreme court was reduced from four to three. By another supplement to the Act of 1806 , enacted in 1810,27 the original jurisdiction of the supreme court was restored in Philadelphia County in cases involving over $\$ 500$, the judges being required to hold nisi prius courts there thirty-three weeks in the year.

To dispose of the accumulation of business a new court called the district court was created for the city and county of Philadelphia, by the Act of March 30 , I $811,{ }^{28}$ to consist of a president and two assistant judges with power to hear and determine all civil pleas and actions where the sum in

\footnotetext{
${ }_{4}$ Smith's Laws, 448.

* March II, 1809, 5 Smith's Laws, 15.

"March Io, I8Io, 5 Smith's Laws, 158.

${ }^{23} 5$ Smith's Laws, 223.
} 
controversy exceeded one hundred dollars. The act was experimental and limited to six years, but the court was such an unqualified success that it was continued and finally made permanent, and similar courts were established later in Pittsburg and Lancaster. From the first this court absorbed the most important legal business of the county and acquired an "enduring reputation as a great law court for the trial of civil issues," ${ }^{\prime 29}$ the greatest this commonwealth has ever seen; but the names of its most famous judges belong to a later period.

No further experiments were tried with the supreme court until 1826 , when an act was passed increasing the number of justices to five and restoring the circuit courts. ${ }^{30}$ The cup of that overworked body was now full. They were required to hear all cases of error and appeal sitting in six districts, to hold a court of nisi prius in Philadelphia, to go on circuit through the counties, beside exercising original jurisdiction in cases of quo warranto and mandamus. Relief came in the Act of April I4, I834, ${ }^{31}$ passed on the recommendation of the commissioners appointed to revise the civil code. Circuit courts were finally abolished and the number of districts reduced to four (the eastern at Philadelphia, northern at Sunbury, middle at Harrisburg and western at Pittsburg); courts of nisi prius continued to be held twice a year in Philadelphia by a single justice for the trial of civil actions involving more than five hundred dollars, reviewable by the court in banc upon motions for new trial or in arrest of judgment.

At the risk of being tedious we have briefly reviewed the many changes in the judiciary system between the Revolution and the revision of the civil code in I834-36, touching on these acts in but a cursory manner without attempting to point out many important features which were incorporated into later legislation and became a permanent part of the system. In fact our subject, like a snowball, has rolled

"Martin's Bench \& Bar, 78.

${ }^{*}$ April 8, 1826, P. L., 265.

"P. L, 34r. 
down the years gathering size and has reached proportions beyond control in a single article. The changes that were made were many of them experimental, some met with success others were doomed to failure; they were forced by the extraordinary growth of the commonwealth in population and wealth and the increase in the amount and importance of the business of the courts. The law of real estate still had first place, land was the principal asset of the inhabitants, and the loose methods of the land office were an invitation to litigation, not to speak of the additional complications arising from Connecticut and Virginia titles. Ejectments innumerable occupied the attention of the courts. But commercial law was every day becoming more important, particularly in Philadelphia, then the first city in the country and for some years the nation's capital. The legal profession enjoyed great prosperity during the early days of independence; recklessness and paper money inflation had increased private debts to an enormous extent and this, with the settlement of the loyalists' estates, filled the dockets with more cases than could be tried. This naturally led to envy and jealousy of the bar, which in Massachusetts broke out in riots directed against the courts, an incident referred to in history as Shay's rebellion.

In Pennsylvania there was no open attack on the courts while McKean was chief justice, a sound lawyer and an upright judge, the sternness of whose judicial deportment and whose inflexible courage were sufficient to awe the mob. No one could doubt his devotion to the cause of independence, but if a democrat in theory he was an aristocrat in bearing. David Paul Brown relates" that "shortly after his appointment, a petition was presented to him directed to the Right Honorable Thomas McKean, Esq., lord chief justice of Pennsylvania, upon which he complacently observed-'these are, perhaps, more titles than I can fairly lay claim to, but at all events the petitioner has erred on the right side." Court was, in his time, opened with great

\footnotetext{
"The Forum, vol. i, 327.
} 
ceremony and form, and the chief justice held the attendants to a rigid observance of duty. There are several cases which illustrate this jealousy of the authority of the court, of which the famous libel case Resp. v. Oswald, I Dall. 3I9, may be taken as an example, as well as the following incident that occurred in 1778 . The chief justice had issued a warrant for the arrest of Colonel Robert L. Hooper, a deputy quarter-master, on a charge of libel. Colonel Hooper informed General Greene, who wrote to the chief justice stating that there was no one to fill the colonel's place and requesting that he might be permitted to enter into a recognizance to appear at court later. The chief justice replied as follows:

"Yorktown, June 9th, 1778.

"Sir:-I have just now received your favor of the 3 d inst., and am not a little surprised that the sheriff of Northampton county should have permitted Colonel Robert L. Hooper, after he was arrested by virtue of my precept, to wait upon you until he appeared before me.

"You say, sir, 'Colonel Hooper waited upon me to communicate his situation, and to know if the circumstances of the army would admit of his absence; but, as the army is just upon the wing, and part of it will, in all probability, march through his district, I could not, without great necessity, consent to his being absent, as there is no other person that can give the necessary aid upon this occasion.'

"I do not think, sir, that the absence, sickness, or even death of Mr. Hooper could be attended with such a consequence, that no other person could be found who could give the necessary aid upon this occasion; but what attracts my attention the most, is your observance that you cannot, without great necessity consent to his being absent. As to that, sir, I shall not ask your consent, nor that of any other person, in or out of the army, whether my precept shall be obeyed or not in Pennsylvania.

"The warrant for the arrest of Mr. Hooper being special, no other magistrate can take cognizance thereof but myself. The mode you propose, of giving bail, cannot be adopted, for many reasons.

"I should be very sorry to find that the execution of criminal law should impede the operations of the army, in any instance; but much more so to find the latter impede the former.

"I am, sir, with much respect,

"Your most obedient, humble servant, "Thomas M'KeAN."

In I799 McKean was elected governor and was succeeded on the bench by Judge Shippen, then seventy years old, who had studied under Tench Francis and at the Middle Temple. Chief Justice Shippen was a patient, practical and discrim- 
inating lawyer and it was from his notes that the first reported cases in Pennsylvania were taken. He indeed formed a connecting link between the courts of the province and those of the commonwealth, having sat on the bench during both periods. This very fact, which caused him to be venerated by the bar, was calculated to increase the hatred with which he and his colleagues, Yeates and Smith, were regarded by the radical politicians. These three judges from their wealth and social connections were regarded as repre.sentatives of the old aristocracy, while the defeat of the Federalist party, in 1799 , left those who had taken office in its day of power exposed to all the dangers of political revenge. The tenure of the judiciary was for life and it filled the earnest partisans of the new democracy with rage to see all the places on the bench filled with those whose sentiments were scarcely less detested than those of the Tories.

The first to be marked for attack was Alexander Addison, president judge of the fifth judicial district which, when formed in $\mathrm{I} 79 \mathrm{I}$, comprised Westmoreland, Fayette, Washington and Allegheny counties, all of the western part of the State. Addison, a Scotchman by birth, had been educated for the ministry, but had changed to the law, and while practicing in the western counties had served as a member of the convention that framed the constitution of I790. An aggressive Federalist, his views were out of harmony with those of the greater portion of the local population, while his strong opposition to the whiskey insurrection did not increase his popularity with the rough inhabitants of that wild region. It was Addison's habit to deliver political sermons from the bench under the guise of charges to the grand jury. These interminable discourses were published and greatly admired by the Federalists, but detested by the Democrats, who, in attending court as parties or jurors, were obliged to listen respectfully to the heavy campaign literature of their opponents. ${ }^{33}$ Judge Addison was particularly fond of dwelling upon the enormities of the French revolu-

"See specimens of these charges in Appendix to Addison's Reports. 
tionists as a warning to good citizens against those admirers of that revolution who were prominent among the Anti-Federalists. Aside from these foibles, Addison was an able, upright and energetic judge, and had toiled ceaselessly to bring order out of confusion in the western district. His learning was regarded with respect by the bar and his firmness had won the confidence of the better class of citizens. When the party of Jefferson triumphed in I799, Addison was a marked man. His leading enemy was like himself a theologian who had turned to the law, had built up an extensive practice and had just been appointed to the supreme court, Hugh Henry Brackenridge, of whom more hereafter.

Instigated by Brackenridge, John B. C. Lucas, a Frenchman, and associate judge of the quartersessions of Allegheny County, attempted to address the grand jury and was prevented by Judge Addison on the ground that in such matters the president judge was the mouthpiece of the court. Lucas brought the matter before the supreme court on a motion for leave to file an information against Addison for misconduct on the bench, but the court declined to interfere, although of opinion that the associate judges had a right to express their opinions. ${ }^{34}$ Lucas again attempted, at the court held June 22, I8OI, to address the grand jury and was again prevented by Judge Addison with the concurrence of another colleague. The paper Lucas intended to . read had nothing to do with the duties of the jury but contained some trifling remarks of a semi-political nature composed perhaps by Brackenridge. ${ }^{35}$ For this act Addison was impeached by the House of Representatives on January 26 , I803, convicted by the Senate by a vote of twenty to four and sentenced to be removed from office and forever disqualified from holding the office of judge in the commonwealth. Judge Agnew has described this trial as "the most flagitious ever urged on by vicious hate and obnoxious partisanship" and the conduct of the legislature in this mat-

\footnotetext{
"Comm. v. Addison, 4 Dall. 225.

"See the printed report of Addison's Trial (1803).
} 
ter has met with general reprobation. Under the circumstances Addison had acted perhaps injudiciously, but his purpose was to preserve the dignity of the court and the punishment he received was unreasonably harsh.

Having tasted blood, the legislature next turned its attention to the supreme court. In February, 1803 , a petition was presented to the House of Representatives by one Thomas Passmore, complaining that he had been arbitrarily fined and imprisoned for a constructive contempt of court in violation of the bill of rights and praying for the impeachment of the judges who had taken part in the proceedings. The matter went over to the following session when it was referred to a committee which recommended the impeachment of Chief Justice Shippen and Justices Yeates and Smith, and accordingly articles of impeachment, adopted on March 23, 1804, were presented to the Senate. On January 5, I805, at Lancaster, then the capital of the State, the trial began. The cause of this impeachment was a proceeding in the supreme court, which will be found reported in the case of Bayard v. Passmore. ${ }^{36}$ The brig Minerva belonging to Passmore, which had been insured in I80r by certain underwriters including the firm of Petit and Bayard, sprang a leak and put into New Brunswick where Passmore abandoned her to the underwriters. Some of the latter refused to pay on the ground that the vessel was unseaworthy when she sailed. An amicable action was entered and the matter referred to arbitrators, who made an award in favor of the plaintiff. Judgment was entered on the award and a $f i$. $f a$. issued, but, on motion, the execution was set aside, and a rule granted to set aside the award, on exceptions filed by the defendant. These exceptions were based partly on irregularities in the proceedings and partly on the merits of the case. While the exceptions were pending, Passmore, who seems to have been exasperated at the delay, posted on a

\footnotetext{
${ }_{3}$ Yeates, 439.
} 
board in the exchange room of the city tavern the following notice:

"The subscriber publicly declares, that Petit and Bayard, of this city, merchants and quibbling underwriters, has basely kept from me the said subscriber for nine months about 500 dollars, and that Andrew Bayard, the partner of Andrew Petit, did on the $3 d$ or 4 th inst. go before John Inskeep, esq., aldermen, and swore to that which is not true, by which the said Bayard and Petit is enabled to keep the subscriber out of his money for about three months longer, and the said Bayard had meanly attempted to prevent others from paying the subscriber about 2500 dollars but in this mean and dirty action he was disappointed in; I therefore do publickly declare, that Andrew Bayard is a liar, a rascal and a coward, and do offer two and a half per cent. to any good person or persons to insure the solvency of the said Bayard and Petit for about four months from this date..

"Philadelphia, September 8, 1902.

"Thomas Passmore."

Thereupon Mr. Dallas, the attorney for Bayard and Pettit, moved for an attachment against Passmore for contempt of court, which was granted and interrogatories filed, which Passmore answered. On the issuing of the attachment the court expressed its opinion that an apology was due to the defendants. The answers of Passmore, while disclaiming any intention to treat the court with contempt, and while admitting that the paper had been posted in a moment of irritation, declined to make an apology to the defendants. It was argued that there was no suit pending when the notice was posted, the proceedings having closed with the award of the arbitrators, but the court was unanimously of the opinion that a contempt had been committed and, as Passmore declined to make any atonement to the injured individuals which would influence the court to leniency, he was, accordingly, sentenced to pay a fine of fifty dollars and suffer imprisonment for thirty days. This sentence. was carried out.

As the law then stood Passmore was clearly guilty, and even if not, the sentence was given after a patient hearing and full argument and amounted at most to an error of law for which Passmore had a remedy by appeal to the high court of errors and appeals, a point upon which he was advised by William Lewis, one of the leaders of the bar. 
But this remedy was not pursued. Passmore paid his fine, served his sentence and sought revenge by the aid of a partisan assembly.

When the time of the trial arrived public feeling had turned in favor of the judges, the better class of newspapers took their side and the bar rallied to their defence; in fact the Assembly found it impossible to procure eminent local counsel to assist them in their odious task and Caesar A. Rodney, of Delaware, was retained for the prosecution. The defendants were represented by Jared Ingersoll and Alexander J. Dallas.

The trial began on the eighth of January, I805, and lasted until the twenty-eighth of the month. ${ }^{37}$ Many witnesses were called and all the litigation which gave rise to Passmore's commitment was minutely reviewed. In summing up Mr. Boileau, one of the managers for the house, argued that Passmore had not been punished because he had committed a contempt of court but because he would not apologize to Bayard, and declared that the court had no authority to direct one individual to apologize to another. His address was a violent attack on English precedents and the legal profession, with the usual platitudes on the rights of man and the principles of the Revolution. Mr. Rodney's speech was more dignified and it is apparent that his task was uncongenial. For the defense the speeches of Dallas and Ingersoll were brilliant and exhaustive, replete with reported precedents as well as manuscript records, which their industry had discovered and which throw much light on the early practice of the courts in attachments. That any doubt could be felt as to the issue of this trial is a matter for wonder, and that thirteen out of twenty-four senators voted for conviction is a lasting disgrace to their names. Fortunately, the prosecutors failed by three votes to obtain a twothirds vote, and the judges were declared acquitted.

One incident of the trial deserves mention. Judge Brackenridge was not on the bench when the motion for the

\footnotetext{
"See printed report of the Judges' Trial (I805).
} 
attachment of Passmore was made and at the time of the argument was returning from a special court in Northumberland County, but was present when sentence was passed. He was not included in the impeachment, but at once wrote to the House stating that he concurred in the opinion of his brethren, and while not courting prosecution, could see no distinction in his case and asked to be included in the impeachment. The House sent up an address to Governor McKean for his removal, which was refused, and when a committee urged that the term in the constitution "may remove" meant "must remove," he replied that he would have them know that "may" sometimes meant "won't."

This offer to stand impeachment with his colleagues was the most courageous act in the public career of the most eccentric genius that ever sat on our supreme bench, about whom a few words may be interesting. Hugh Henry Brackenridge, born in Scotland, of poor parents, was. brought as a child to this country. By teaching school he saved enough to attend Princeton, where he became a tutor, studied divinity and served as a chaplain in the Revolutionary army. In $I 778$ he commenced the study of law with Samuel Chase, afterwards a justice of the Supreme Court of the United States, and, locating at Pittsburg, soon became a leader of the western bar. During the whiskey insurrection Brackenridge's conduct was not free from suspicion. His opinions were opposed to the excise tax and if he did not join the insurgents he did not take a very firm stand against them. He was marked for arrest by Hamilton, but was saved, it is said, by James Ross, the rival leader of the bar and afterwards United States Senator. At the bar he was noted for his shrewdness, wit and eloquence, and was a writer of considerable talent; "Modern Chivalry," a satirical work from his pen, has gone through several editions. On the bench he did not display the same power as at the bar; his opinions were racy, but not profound and fail to do justice to his real learning. He was an untiring student, but his dislike of convention led him at times into a show of flippancy. The enmity between Judges Yeates and Brack- 
enridge was a curious incident of the times. It probably dated from the time of the whiskey insurrection when Yeates served as one of the commissioners to deal with the insurgents. No two men were ever more dissimilar in appearance, habits and opinions; Judge Yeates a tall, florid, portly man, rich, aristocratic and fond of society, Brackenridge dark and sallow, of moderate means, a bookworm and recluse, and absolutely indifferent to his appearance. An examination of the reports will show that the associates rarely agreed, and the position of Chief Justice Tilghman must have been peculiarly difficult. Indeed the eccentricities of Brackenridge, if half the traditions are true, would almost amount to insanity, but it is difficult at this day to say whether his want of judicial decorum arose from this cause or from his utter contempt for social conventions. Among the odd stories told of him is one narrated by David Paul Brown: ${ }^{38}$

"During the time, as has been said, the circuits existed, a friend of the judge, riding in his carriage in the western part of the state, while a prodigious storm of wind and rain prevailed, saw a figure approaching, which resembled, what might be conceived of Don Quixote, in one of his wildest moods, a man, with nothing on but his hat and boots, mounted upon a tall, raw-boned Rosenant, and riding deliberately through the tempest. On nearer approach he discovered it to be Judge Breckenridge, and upon inquiring what was the cause of the strange phenomenon, Breckenridge informed him, that seeing the storm coming on, he had stripped himself and put the clothes under the saddle; 'because,' said he, 'though I am a judge, I have but one suit, and the storm, you know, would spoil the clothes; but it couldn't spoil me." "

The interminable criticisms of and complaints against the judiciary during the early nineteenth century were in a large measure due to the fact that judges held office for life. The same processes were to be seen at work in the other states, culminating in the abolition of life tenure and the substitution of a term of office varying, under the different constitutions, from one to twenty years. In Pennsylvania this result was accomplished by one of the constitutional amendments adopted in 1838 , by which the terms of

"The Forum, vol. i, 404. 
the supreme court judges were fixed at fifteen years and those of the common pleas judges at ten. This change was not adopted without vigorous opposition on the part of the leaders of the bar $^{39}$ and is a subject upon which opinions differ to-day. We may suspect that, however the political leaders who advocated the change may have declaimed against the dangers of caste prejudice, favoritism and despotic conduct, they were looking at the offices with envious eyes and plotting to divert the meagre salaries to partisan purposes. This was the period when American political life, in its outward aspects at least, reached its lowest depths of degradation, and that the judiciary should suffer thereby was inevitable. Americans had yet to learn that democracy was not synonymous with vulgarity and provincialism, and that the American Revolution had not severed us from the traditions of our race, or the French Revolution emancipated us from the rules of social decorum. The American "Sans Culotte" was an unlovely type, an iconoclast and a bitter partisan, and that he should have done his best to add the judiciary to the spoils system is not the least count in his indictment.

The citation of English decisions in the opinions of the courts greatly exasperated the radical element. What were these precedents but the rags of despotism, who were the judges that had rendered them but tyrants, sycophants, oppressors of the people and enemies of liberty! There was danger that our courts might be contaminated by the source from which they drew their inspiration, so an act was passed March I9, I810, ${ }^{40}$ which provided that it should not be lawful to read or quote in any court of this commonwealth, any British precedent or adjudication which had been given or made subsequent to the fourth of July, I776, except those relating to maritime law or the law of nations. Upon this act Judge Brackenridge wittily remarked:

\footnotetext{
"Debates of $\mathrm{Pa}$. Constitutional Convention of 1837 , vol. $x, 148$ et seq.

${ }^{\omega}$ P. L. I36.
} 
"Were it not that I should be unwilling to enter into a contest with the legislature, where public opinion, or prejudice is on their side, I might be disposed to question the constitutionality of this act. It would seem to be abridging the right of the judiciary, to hear all reason on a question before them.

\section{What is't to us}

Though it were said by Trismegistus?

"But if we are to hear the saying of a lord, years, or centuries ago; and before the $4^{\text {th }}$ July, 1776 , why not what another lord has said since, to explain or contradict the adjudication? The fact is, early decisions were, many of them narrow; and why drink out of the neck of a gourd, rather than out of an open goblet; more especially if the fountain was muddy, out of which the gourd was filled; the stream of law in that country, now runs more clear in particular cases than centuries ago; and it will always remain so, the law being an improvable science."

\section{This act was repealed in 1836.41}

It may be said, however, for those who railed against the judges, that many of the lay associates set anything but a good example of judicial dignity, and quarreled even to the point of coming to blows and dragging each other from the bench. The law judges, who rode the circuits, manfully attempted to preserve in the $\log$ court houses of remote counties the dignity of Westminster Hall, and added to their unpopularity with the uncouth inhabitants by instructing them in manners as well as in the law. In his "Recollections of the West," ${ }^{2}$ Judge Brackenridge's son, himself also a judge, gives an amusing picture of the first court held in Butler county. The court house was a log cabin into which bench, bar and the entire village population were crowded. The audience hung from the rafters like bats, and when these were cleared away by the sheriff, a big Irishman objected to being removed. The Court sentenced him to an hour's imprisonment for contempt, whereupon the sheriff was greatly puzzled as to what he should do with his prisoner, as there was no jail. It was finally decided that he should be incarcerated in a pig pen, emptied to prepare a feast for the court, but the prisoner was too much for his captors and made his escape into the brush.

\footnotetext{
"Brackenridge's Miscellany, 525. Act of March 29, I836, P. L., 224.

"Recollections of the West. H. M. Brackenridge. See extract in Haz. Pa. Reg., vol. xiv, I72.
} 
During most of this period the supreme court was presided over by chief justices of reputation equal to almost any, and superior to most of those who have sat in American state courts, Tilghman and Gibson. William Tilghman ${ }^{43}$ came of a family of distinguished lawyers, his father being secretary of the Provincial Land Office, and his maternal grandfather, Tench Francis, the bar-leader of the provincial court of his time. His first judicial appointment was by President Adams on March 3, I8oI, to the circuit court of the United States for this circuit; hence he was one of the so-called "midnight judges," commissioned a few hours before Jefferson took office, and legislated out of office in the following year. In 1806 he was appointed chief justice by Governor McKean on the recommendation of his cousin, Edward Tilghman, who declined the office. His appointment gave offence to some of the minor Democrats, but the Governor, although a leading member of that party, having once made up his mind on the subject, was not to be moved.

"A committee, consisting of Duane, Lieper, and others, were appointed by a town meeting to wait upon him, to inform him that the democracy of Philadelphia were utterly opposed to the nomination of William Tilghman as chief justice of Pennsylvania. The committee were introduced into the executive apartments, and the governor received them in his civil but reserved and aristocratic manner, treating them simply as his constitutents; when, however, they announced themselves as the representatives from the democratic party -the sovereign people- he bowed most profoundly, and inquired of them what the great democracy of Philadelphia required of him. They proceeded, and stated the purposes of their delegation, and in pretty plain terms gave him to understand that the appointment of $\mathrm{Mr}$. Tilghman would never meet the approval of the democratic party. 'Indeed,' said the governor, inform your constitutents that I bow with submission to the will of the great democracy of Philadelphia; but by $\mathrm{G}-\mathrm{d}$, William Tilghman shall be chief justice of Pennsylvania."

The confidence of the Governor was justified by the long and distinguished career of his appointee, whose judicial decisions are marked by a comprehensive knowledge of the common law and an unusual clearness of diction. "Other Judges," says Binney, "may have had more learning under

"See Binney's Eulogy, 16 S. \& R., 444; The Forum, vol. i, 343. 
their immediate command,-none have had their learning under better discipline, or in a condition more effective for the duty upon which it was employed."

An adequate life of his great successor, John Bannister Gibson, has still to be written. ${ }^{44}$ Appointed to the common pleas in 1812 and to the supreme court in 1816 , of which he became chief justice in 1827 , his reputation increased with years, and common consent assigns to him the first place in our judicial history. "Abroad," said Chief Justice Black, "he has for many years been thought the great glory of his native state." Chief Justice Gibson has been credited with an abhorrence of the petty and prosaic details and drudgery of the law, qualities that would have militated against a successful career as an advocate, but given a problem, no judge could grasp it more firmly or dispose of it more readily, and he was master of a style which in vigor of expression and condensation of thought is unrivalled, "When he brought the lens of his mind to a focus, its power was resistless." For one act in his career he was subjected to some criticism. The constitutional amendments of 1838 substituted a term of fifteen years for life appointment and the commissions of the judges on the bench were to expire at intervals of three years. At the suggestion of his colleagues, the chief justice resigned in 1838 , and was immediately reappointed, and thus, instead of holding to the shortest term, enjoyed the longest. The necessity for this action was no doubt humiliating to him, who could hardly have resumed practice at that period of his life, but on the other hand his loss to the state would, at that time of transition, have been irreparable, and when his term expired in I85I, he was re-elected almost without opposition.

If space permitted, it would be proper to say something of the bar at this time, which was particularly distinguished, and made the name of a "Philadelphia lawyer" a by-word for legal astuteness.

During the greater part of this period Philadelphia was

\footnotetext{
"See Eulogies in Appendix to Ig Pa. State Reports, and W. A. Porter's Essay.
} 
the leading city of the nation, both in population and wealth, and the achievements of the local bar attracted national attention. Such leaders as William Lewis, Jared Ingersoll, William Rawle, William Bradford, Alexander James Dallas and Horace Binney, both in private practice and public office, exhibited talents that were admired and esteemed by their contemporaries and served as models for their students and successors. Indeed, so much has been said about the good old times, that we are often in danger of minimizing professional progress, which, in the nineteenth century, has been in the nature of a forced march to keep pace with the flying wheels of Father Time's steam and electric chariots. If we have lost anything, it is the pride of a small and exclusive professional body and the sense of responsibility that accompanies such pride, but we have gained in breadth of view, in depth of sympathy, and, perhaps, in greater freedom from prejudice.

William H. Loyd, Jr. 